\title{
STUDIES ON THE PALPEBRAL AND CONJUNCTIVAL HEMORRHAGE APPEARS TO BE PRODUCED BY THE IRRITATION, OTO-RHINO-LARYNGOLOGICAL OPERATION.
}

\author{
By
}

\author{
Y. SUZUKI, E. SAITO, I. MIYABE AND Y. SAKAMOTO \\ From the Department of Oto-Rhino-Laryngology, School of Medicine, \\ Keio University (Director: Prof. T. Nishihata)
}

It is not an infrequent experience to see localized subcutaneous hemorrhage or congestion in the eyelid, conjunctiva or neck not always ipsilaterally but sometimes contralaterally after an oto-rhinolaryngological operation, especially after a paranasal sinus operation, in spite of disapproval of abnormal observation, such as hemorrhagic diathesis etc.

The authors now report those on account of having experience of the same several cases as above mentioned ones, and are inclined to trace their origins.

Autonomic nervous function of these patients was situated on very unstable or unbalanced condition, especially circumstances of parasympathetic function was conspicuously excitable.

This hemorrhagic phenomenon as a result of E. Saito's experimental study on the rat, is concluded as follows: Namely irritation caused by various excessive stimulations from operation or its injury, chiefly through the agency of autonomic nervous fibers and abnormal constitutional factor, i.e. remarkable unbalanced condition of autonomic nervous function, bring on vascular disturbance with edema, vasodilatation, stagnation of blood cells and hemorrhage.

These facts have included the authors to interprete the hemorrhagic lesion in the eyelid as a manifestation of the Reilly's phenomeron.

\section{耳鼻咽喉科領域手術時の過剩刺戟によると思われる 眼瞼皮下ならびに結膜下出血について}

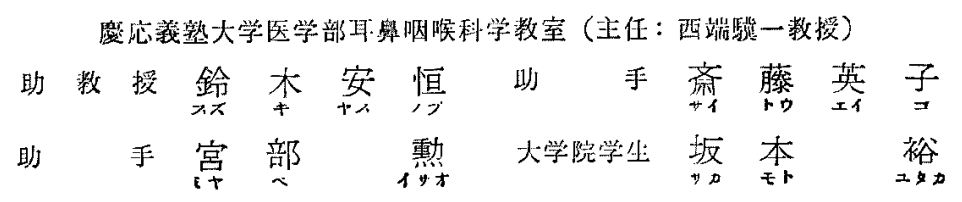

\section{I はしがき}

われわ机が日常矢施している耳鼻咽䛈科領域の手術と くに副鼾焢炎根本手術などに際して，出近性素因など の異常もみとめられないにるかららず，ときに眼臉部 や頸部の皮下出血斑や腿球結膜の冭うつ血や出血斑の出 現をみることがある。しかる手術側のみならず手術反刘 側にるかつる現象の生ずることは，手術時の直接的損傷 などによるるのと考えるのは妥当性を欠くよらに思われ

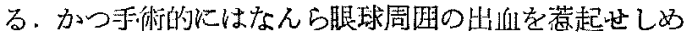
るごとき撌傷を起さ妵例が多い，從来は持そらく手術 時气の部位を強く圧迫したり，その他の外部からの直接

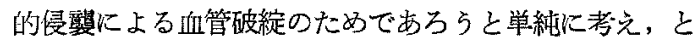
くに深く追求はされなかつたるのと思われる，われわれ も手術時に細心の注意をはらつたにすかつわらず，上記 の症状を呈した数例の症例を経黜したのでこつに報告し

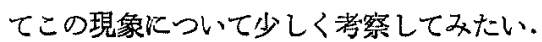




\section{II 症 例 報 告}

（症例 1) 患者は 22 才の女子, 両側慢性副鼾腔炎にて 某開業医によって昭和 32 年に両側上顎洞ならびに穊骨 洞根本手術をらけ，いったん症状は軽快したが，昭和 34 年秋頃からしだい、膿粘液性藇汁の流出著明となり，左 側煩部の軽度の腫脹を伴い昭和 34 年 10 月 初旬 来院し た.レ線像ならびに鼻内所見から術後性煩部息腫などは 考えられず, 術後性副鼻腔炎急性增悪症之診断し，10月 下旬左側上䫓洞再手術のみ実施したが，上顎洞内は洀痕 性肉苯充満し対孔は閉塞して沶り，これをすべて除去し たのちあらたに対孔を Denker 氏法により，なるべく 広く開放した．術後第 2 病日頃上り写真に示すごとく， 左側上眼瞼部皮下に出血斑の出現を認めた。な㧍術前の 血液検查ではザーリー102\%, 赤血球数 309 万, 白血球 数 6200 , 出血時間 3 分 30 秒で, 軽度の 高色素性瑻血の あるほかはとくに異常を認めず，血圧 118〜78, 尿所見, 心電図所見にも全く著变はない，術中ならびに術後の出 血は一般にや小多量であり，Adona， Manetol などの止 血凧を比較的大量に使用した. (Adona 10mg を6時間 毎筋注 5 日間, Manetol 1 筒朝夕 3 日間), また眼臉部 出血斑の出現後の検査では, Prothrombin 時間 15 秒, Rumpel-Leede 現象陰性, 血圧 128 84, 出血洔間 3 分, 凝固時問開始 6 分 30 秒完了 10 分 30 秒にて出血性素因 のためとは全く考兄られず，また出血部附近の手術的直 接損傷のためとも思われない点から, 他の体質的素因を 考えて自律神経機能を検查した結果, Adrenalin 試験で 血圧上杽度陽性, 脈搏毎分 78 から 92 亿增加, 心悸六進 あり，判定は（十）であつたのに反し，Pilocarpin 試

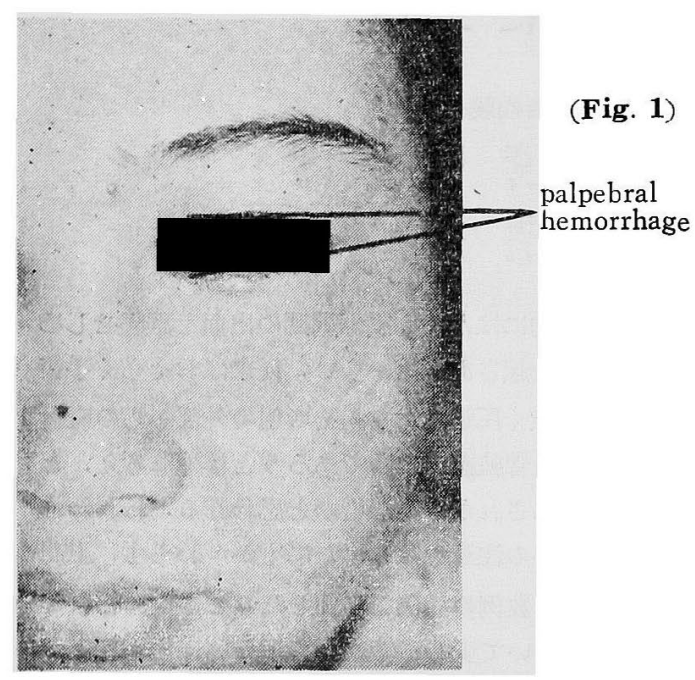

験では喠液分泌量が 1 時間に $170 \mathrm{cc}$ に達し, 多量の発 汗を認め, 脈搏子 76 から 104 亿增加し, 判定は(H)で, あきらかに Vagotonie の状態であつた. また Atropin 試験では口内乾燥感が著明で心悸六進あり, 軽度の脈搏 增加もあり, 判定は (H) であつた.

以上の検查結果より自律神経機能は極めて不安定な状 態にあり，とくに副交感神経機能の與奮性亢進が著明で あると推察できる. (Fig. 1 挿入)

(症例 2) 患者は33 才の男子. 出血性素因の既往はな く, 家族歷にも特記するものはない，学童期より鼻汁過 多, 後䦩漏就よび畀閉塞感著明にして, 慢性副鼻腔炎と 鼻中隔缶曲症あり, 昭和 32 年 10 月右側副鼻腔多洞根本 手術と鼻中融矯正手術を実施したが，写真に示すごとく 第 2 病日より画側眼瞼部ならびに右眼球結膜に出血斑を 生じ, ほとんど同時に右耳後部から頸部にかけ, また右 上腕作側に比此的広範囲に特よふ皮下出血斑を認め た. 術中および術後タンポン ガーゼ除去時の出血は比 較的多量であつた. 術前の血液検査では血色素ザーリー $98 \%$, 赤血球数 489 万, 白血球数 8100 , 血圧 142 82, 出血時間 2 分である. 術後の出血時間は 3 分 30 秒, 凝 固時間は開始7 分, 完了9 分 30 秒で全く正常範囲にあ り, Rumpel-Leede 現象陰性, 心電図所見では semivertical position, sinus bradycardia があるほがは異 常は認めれらず，尿所見でも特記すべき異常はない，血 液 Wasserman 反応は陰性である。術前の鼻内所見は 鼻中隔は右方に高度に彎曲し，耐中鼻道ならびに嗅裂は ほとえぞ閉鎖し，左篩骨胞は高度に発達して両中鼻甲介 粘膜は浮腫状に腫脹し，両下鼻甲介粘膜は中等度に肥厚 するも，咽頭および耳には異常所見は認められなかつ た. (Fig. 2 插入)

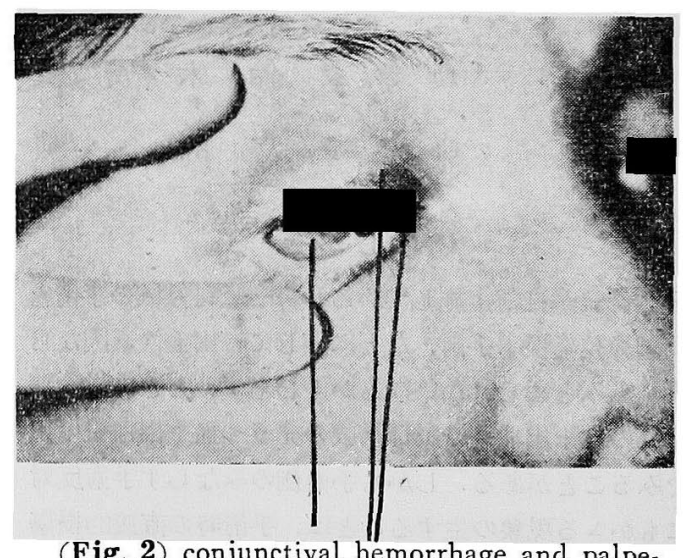

(Fig. 2) conjunctival hemorrhage and palpe- 
（症例 3）患者は 32 才の男子. 17 才の洔肺結核症の羅 患以外には特記すべき既往症はなく，出血性素因も認ぬ られない. 昭和 31 年 1 月慢性副鼻腔炎にて左侧上顎洞 ならびに篩骨洞根本手術を实施したが，手術時とくに眼 臉部出血をひきおこすよらな損傷はなく,術後もAdona, Thrombogen および Vitamin-C などの止血㧩をや子 多量に注射したが, 手術翌日患部より出血をや〉多量に みとめ, 第3 病日にいたり両側上下腿瞼部の皮下出血斑 を認めた. (写真参照)

な打術前の血液検查では赤血球数 550 万, 白血球数 5100 ，血色素ザーリー75\%，尿所見などにも異常を認め なかつた. (Fig. 3 挿入)

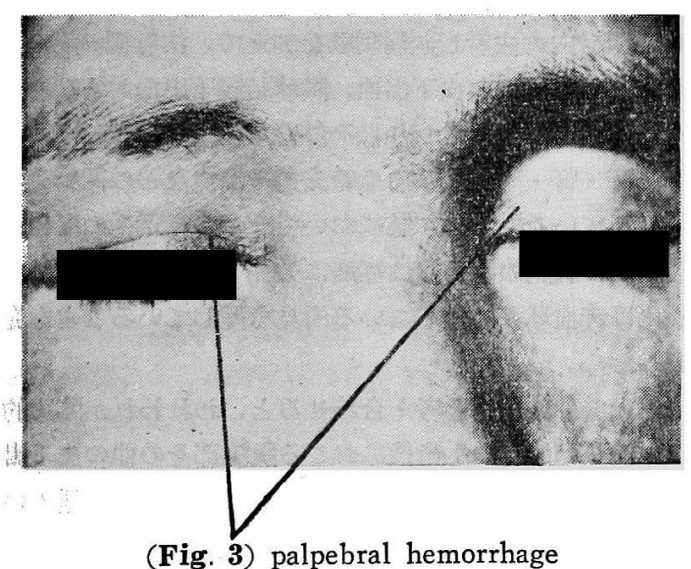

(症例 4) 患者は 25 才の男子. 約 3 年前より両側鼾閉 塞並びに後鼻漏を認めていたが，昭和 34 年 5 月頃より 毎月 1 回位発作的に比較的多量の鼻出血あり, 本年 2 月 以降は持続的な血性鼻汁を認め, またしばしば鼻出血も 起り， 7 月某病院を訪れ鼻咽頭線維腫の䛦断をらけ，そ の後も鼻出血は少量ながら持続し 7 月 27 日手術の目的 で慶応病院に来院した.

既往症としては約 3 年前に両側下甲介粘膜切除術なら びに入院直前の7 月下旬に鼻中滆燆正手術をうけている か゚，そのほかには特記すべきものはなくとくに出血性 素因の既往はまつたく認められない，家族歴にも癌・結 核・血液疾患などの遗伝関係多存在しない，入院時の舅 内所見は前鼻鏡検查では右側総鼻道から下鼻道にかけて 後鼻孔に近く暗赤色のや〉致死状の腫瘍組織が充満し, 後鼻鏡検查では後鼻孔は雨側とも暗赤色の腫昜組織で后 とえど閉塞され，腄瘄茎部ははつきりしていない，入院 時の血液検查では血色素ザーリー89\%, 赤血球数 447 万
白血球数 6600 , 血小板数 202000 , 出血時間 (Duke 法) 3 分 30 秒, 凝固時間 (Lee-White 法) 11 分 30 秒, 赤血 球抵抗最小 0.44 , 最大 0.30 , 毛細管抵抗は陰圧 $300 \mathrm{~mm}$ で 2 個，血中クロール108.0mEq/L, ナトリウム $146.2 \mathrm{~m}$ $\mathrm{Eq} / \mathrm{L}$, カリウム $4.82 \mathrm{mEq} / \mathrm{L}$, 血液ワッセルマン反応陰 性でとくに異常を認めず，检尿・榆便の結果もまつたく 異常なく, 17Ketosteroid \& $9.02 \mathrm{mg} /$ day, $0.524 \mathrm{mg} / \mathrm{dl}$ で正常值である. 旰機能の各榆査に括いてもすぺて正常 值を示し肝機能障碍は認められない，心電図検査ては不 完全右脚ブロックが認められた。鼻咽頭腫瘍摘出術は 8 月下旬に，手術前投薬として Ravona 2 錠, Opystan $70 \mathrm{mg}$ 打よび硫酸 Atropin 1.0cc 注射を用い, 笑気・エ ーテルガスの全身麻酔下に実施された. 右上罘洞, 箒骨 洞ならびに蝶形骨洞粘膜はポリープ状に肥厚し，膿汁の 貯溜は認められず，上頡洞経由に腫瘍を望見するに鼻咽 頭上壁や蝶形骨洞前壁部には腫瘍茎部はまつたく認めら れず，軟口蓋を口腟内より挙上して腫瘍部を引き出すと 鼻咽頭右側壁に近く腫場茎部をみいだし，この部周囲を 充分䗗把した，術中出血はきわめて多量であり，輸血な らびに輸液は十分実施して手術を続けた。術後 2 病日よ り写真に示すことき右眼臉皮下出血扢よび腫脹を認め た. 術創のタンポン・ガーゼは第 4 病日より部分的に少 しづ抜去した．この際の出血も一般に多量であり，術 前および術後比較的長期にわたり Adona, Manetol の 筇注を大量に持続した。

術前㳙前述の諸検査成績を得たが, 術後さらに自律神 経系機能検查を実施したところ, ず薬物的検査の中, Adrenalin test では最高血圧は100から126 亿增加,脈 搏は64 から88 に增加, 副症状として心悸六進と四肢振

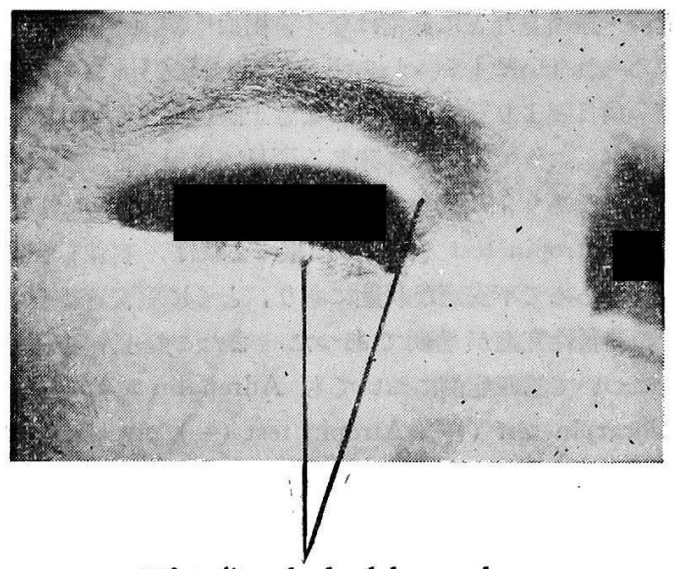

(Fig. 4) palpebral hemorrhage 
䫄を軽度に認めるもその他の症状はなく，判定は（一） である. Pilocarpin test では喠液分泌量が 1 時間 $100 \mathrm{cc}$ に㸝よび, 軽度の発汗と認め, 脈搏の增加も著明で判定 は（H）である. Atropin test は口内乾懆感を軽度に 認めるむ脤搏增加, 心悸六進, 瞌孔散大はなく、判定は

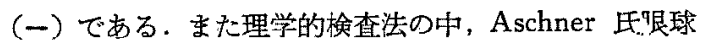

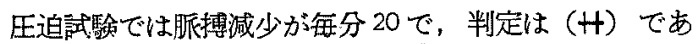
り, Czermak-Hering 氏頚動脈洞圧迫試験では脈搏减少 が毎分10で判定は（十）であり，以上の結果は副交感 神経緊張六進々判定でき，きわめてアンバランスな状態 にあつたものと推察できる。

\section{III 総括および考按}

耳奥咽㑨科須域の手術後に，手術野加ら離わた部位や 直接手術的侵翼とは関保のないと思和机る部位に皮下出 血が認められることがあり，とくにこの中では副鼻腔炎 の手術後の腿睑皮下あるいは眼球結嗼下に認められる出 血が多く，高度のときは顔面・頸部・胸部拉よび上肢に む及ら広範囲な溢血として認められる症例も経験した。 (症例 2). 従来は琹らくその部位を強く王迫したりそそ の他の外部からの直接的侵繁による血管破綻のためであ ろらと単純考え，とくに梁く追求はされなからた。乙 かし手術時細心の注意をはらつて手術操作をして，皮䖉 の压迫などをしなくても，また出血性素因乞の他の異常 が涊めら机なくても，かつる現象の生ずることを以上数 症例をあげて㙂告した．乙かも眼臉皮下出血や結膜下出

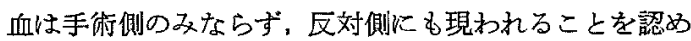
たが，このことから考兄ても手術時值接乞の部を代迫 したり，あるいは手術操作による直接的の血管破綻とは 考之難い。

第一店例に扣いては軽度の高色素性昘血のあるほか， 血液・尿所見などに異常はなく，出血性素因るまつたく 認められないにもかつわらず，左側上顎洞根本再手術後 第 2 病日槽より写真に示すことと眼脸皮下に出血斑を みたが，こつで大いに與味する所見は自律神释㙨能恰查 の結果であり, Adrenalin test (十), Pilocarpin test (H), Atropin test (H) の結果によれば，自律神経機 能はきわめて不安定な状態にあり，とくに副交感神経機 能の與舊性光准が著明であつた．またこの自律神経機 能について第四症例に括いても Adrenalin test (一), Pilocarpin test (H), Atropin test ( $(-)$, Aschner 眼 球壬迫試験 $(H)$ ，Czermak-Hering 项動脈洞圧迫試験 （十）の結果を認め, 副交感神経緊張立進が 頙著であり， この自得神経㙨能のアンバランスと云ら体誓的因子が手
術後の眼瞼皮下出血や結膜下出血就よびその他の皮下出 血発現の一要因になつているのではないかと推察され

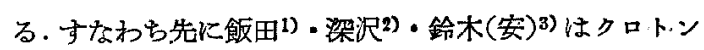
油を使用してモルモットの口腟内刺践によるショック様 症状の発現を認め, その際に遠潭諸葴器に浮董・充らつ 血・出血などの血管系障碍が起ることを観察し，このシ ヨック様症状と血管系の障碍が植物神経安定刻のChlorpromazine をあらかじめ投与することによつて阻止で きることを確かめ，これは主として植物神経系を介して 血管運動神経の過剩反応によるるのであると推察してい

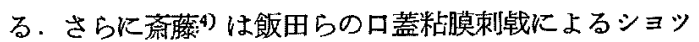
ク央験に用いた方法に準じて、クロトン泊を使用してラ ッテの藇腔倒壁粘膜下より煩部に，また口腔内上り煩部 皮下組㱍内に注射し過剩刺儎を加えて，注射側のみなら ざ反対側の腿臉部皮下出血, 眼球結膜下出血拉よび壊死

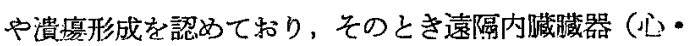
肺・肝・腎・副腎）にも血管充盈や出血などの循環障碍 を認めている。ことに肺においててこの循環系の変化が 著明で, 肺胞の毛細管は極度に充盈さらに出血して肺実 質内は赤血球で充満している所見を呈していることを発 表した。

以上の実験結果と考光合わせると，われわれが臨床的 に経験した前記の手術後に和こる眼盼部乞の他の皮下出 血は，やはり手衍時（あるいは手術創）に和ける種々の 刺戟が主として植物神経線維を介して過剩反店を起し， 植物神経機能の強度のアンバランスな状態を示す体質的 因子とあいまつて出血などの血管系障碍を起したものと 考えることが妥当性があるように思われる，もちうん斎 藤4) のラッテ腿睑部の出血性変化の出現率 (鼻腔側壁粘 膜下にクロトン油注射例では 同側の出血性变化は 19 例 中 15 例，反対側出血は 19 例中 9 例) と臨床例に扣ける 手術時の眼臉部その他の出血性変化の出現率とを比較す るときには，かなりの著しい相違があり，またこの動物 実験ではかなりの割合で死亡例が存在し，内臓諸蔵器に も相当の循環系を主とする変化が認められている.これ らのことは動物実験ではクロトン油注射（0.1〜0.2cc） が，かなり強い持続性の刺㦸であること，また刺㦸に対 する生体の反応が動物と人間では相当にことなることが 推察され，そのほか種々の条件がことなるためと考えら れ，臨床例之動物実験のそれぞれの結果にその距離を感 ぜさるをえない，しかし動物実験に批いてえた知見は臨 床に和ける事実を説明するのに多くの示唆を与えるもの 之信ずる次第である. 
植物神経分布が㯪めて豊富と云われる耳奥咽喉科領域

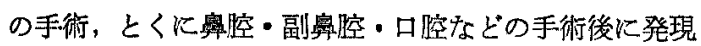
する眼臉部およびその他の部位の皮下出血斑を植物神経 の過剩反応の結果と考えるとき，手術部位えの種々なる 刺㦸がときに全身的合併症の出現の可能性あることを示 唆するものであり，手術後のわずかな局所変化の出現で あつても当然全身的变化の出現の可能珄を洘慮して, 十 分嫃重な臨床観察とその连やかな対策の必要があるるの と思考する、まだ梁沢²の Chlorpromazine を用いての モルモットのショック様症状㧍よび遠隔諸蔵器の血管系 障碍の阻止実験の結果から考えてる，臨质的に手術前に Chlorpromazine, Pyrethiazine, Opystan などのカクテ

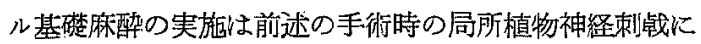
よる全身的過剩反応を未然仿防あるい、軽減する意味 からも必要ではないかと推察する次第である。

ちなみに前述の症例報告した全症例とも手術前に Chlorpromazine, Pyrethiazine, Opystan などのカクテ 儿麻酔はまつたく使用しなからたすのである。

\section{IV むす び}

耳兽咽咲科領域の手術後に，手術野から離れた部位や 直接的侵融に上る血管破綻などがないと思われる部位に 皮下出血が認められることがあり，とくに副䶊空炎の手 術後の腿臉皮下あるいは腿球結膜下に認められる出血が 多く，高度のときは顔面・頸部・胸部および上肢にもお よふ広範围な溢血として認められる症例を経験したので その数例を報告した。これらの症例は小べて手術時細心 の注意をはからて手術操作をし，皮膚の压迫や損傷など をせず，また出血性素因などにも異常は認められなかっ た.この出血や溢血現象は手術側のみならず，反対側に も現われることを認めている. Adrenalin, Pilocarpin および Atropin test などの自律神経機能を検査した第 1 例特上び第 4 例の結果仗，自律神経機能はともにきわ めて不安定なアンバランスな状態にあり，とくに副交感 神経機能の興鹪性亢進が著明であり，この体質的因子あ るいは状態が，手術後の腿臉皮下出血，結膜下出血およ
びその他の皮下出血の発現の一要因になつているのでは ないかと推察した。

これは斎藤の動物実験においてシッテの奥腔側壁粘膜 下やロ腔より煩部にクロトン油を注射して過㮃刺战を加 えると, 注射側のみならず反対側の眼瞼皮下出血, 眼球

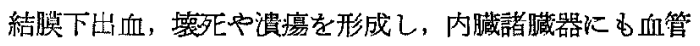
充盈や出血などの循環障碍を認めている。

以上の实験結果上考点合わせて，われわれが臨床的に 経驞した前記の手術後に起る皮下出血や溢血は，手術時 あるい㤹術創に括けるいるいるの刺战が主として植物 神経線維を介して過剩反応を起し，桓物神経機能の強度 のアンバランスな状態を示守体質的因子とあいまつて出 血などの血管系障碍を起したすのと考えることが妥当で あるように思われる。

植物神経分乕のきわめて豊富といわれる耳鼻咽腒科領 域の手術ては, 以上の術後の皮下出血や溢血を主に模物

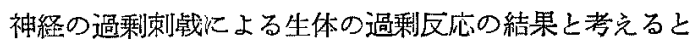
き，手術部位えのいろいろな刺㦸がときに全身的合併淀 の出現の可能性のあることを示唆し, わずかな局所変化 であつても当然全身的变化の出現の可能性を考慮して十 分慎重な臨床的観察とその速やかな対策が必要であるも のと思洛する。

\section{文献}

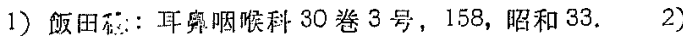

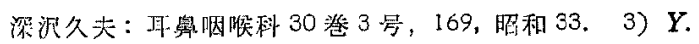
Suzuki, M. Iida and H, Fukuda: Keio Iournal of Medicine, vol. 7 Nov. 1958. 4) 紊藤英子：日 耳棞 63 巻 10 号 2214, 昭和 35 .

稿を終るに臨み，恩師西端驜一教授の御舁篤なる 御指導と御校閲を深謝致します。

な叔本諭文の要旨は昭和 35 年 2 月, 耳奥咽喉科 学会関東地方会第 367 回例会に拈いてロ述した。

（原稿到着=昭和 35.12.28日） 